\title{
ATTITUDINAL CHANGES AT THE PRESIDENTIAL ELECTIONS IN ROMANIA WITHIN THE 30 YEARS SINCE THE FALL OF THE COMMUNIST REGIME
}

DOI: http://dx.doi.org/10.18509/GBP.2020.54

UDC: 328.13:342.843.1(498)

\author{
Alina Viorica Dumitrascu ${ }^{1}$ \\ Vasile Pop ${ }^{2}$ \\ Nicoleta Bira ${ }^{3}$ \\ Andrei Ducman ${ }^{4}$ \\ Camelia Teodorescu ${ }^{4}$ \\ ${ }^{1}$ University of Bucharest, Faculty of Geography, \\ Department of Geomorphology; Bucharest, Romania \\ ${ }^{2}$ St. Elefterie Church, Bucharest, Romania \\ ${ }^{3}$ Middle School, Oltenita, Calarasi County, Romania \\ ${ }^{4}$ University of Bucharest, Faculty of Geography, Department of Human and Economic \\ Geography; Bucharest, Romania CAIMT (Research Center for Integrated Analysis and \\ Territorial Management), University of Bucharest, Romania
}

\begin{abstract}
Romania, like other countries in Eastern Europe, has gone from a totalitarian, communist, to a democratic political regime. This change in the political regime has also brought opportunities regarding the election of the president. After 1989 the presidential elections in Romania have had different orientations of the population regarding the political membership of the candidates. The study follows these mutations regarding the results of the presidential elections, in the two rounds, placing the political belonging of the candidates in the final round in the middle of general attention. The result highlights the relationship between those who have given a negative vote to a candidate, who has reached the final round, and those who gave a positive vote to the candidate they have simply chosen out due pure political beliefs. Within the 30 years since the change of the totalitarian political regime, the population of Romania has reached a major political change, oriented towards liberalism, in a very convincing percentage. These changes are based on a number of factors, which the study has analyzed on each geographic-historical province and, on each administrative unit, it has analyzed the componence of these provinces. The analysis has been made from the point of view of population structure by age group or socio-professional analysis, as well as from the level of education by historical provinces and therefore it explains the result obtained in the presidential elections.
\end{abstract}

Keywords: presidential elections, communism, political regime, liberalism, democracy

\section{INTRODUCTION}

In the 30 years since the fall of the communist regime, Romania has gone through a period of transition from the communist grounded mentality to the liberal doctrine, so that the most conclusive analysis can be performed at the level of geographical- historical regions, accompanied by the analysis on counties [4], [8], [9], [11]. Thus, the article proposes to identify the evolution of the main poles that recorded strength points in the 1989 
Revolution, of the counties with a lower wage level and of their close relationship with the social-democratic ideology, of the counties that represented almost always poles of liberalism, but also the main general direction on what voting concerns, of the historical regions of Romania.

The ideology was very important over time, and the candidate was posted in the secondary plane, so that the most conclusive method of analysis was the one represented by doctrinal division [1], [3], [2], [7], [12]. The two doctrines that were permanently in the second round were represented by the social- democratic doctrine and the liberal one. In the evolution presented we will see how the proportion of liberalism gradually increased, with a small obstacle noticed in 2000 [13], [5], [14]. Thus, in each election campaign there were motivations for which certain counties or regions voted massively in a certain direction, and this article targets to identify them and give clear expression to them as a consequence of the vote offered by people [6], [10].

\section{METHODOLOGY}

The analysis was carried out by collecting the electoral data of the presidential elections of 1990, 1992, 1996, 2000, 2004, 2009, 2014 and 2019, data provided by the Central Electoral Bureau. The data collected by the institution in charge were divided by counties, and when making the maps, we grouped them by geographical and historical regions of Romania. The maps were made for the second round of the elections of the years mentioned above for the following regions: Banat, Crișana, Dobrogea, Maramures, Moldova, Muntenia, Oltenia and Transylvania. The software used to create the maps was represented by inkScape 0.97, while Adobe Photoshop CS6 was used for the map collages. Within the maps there were selected the doctrines of the candidates of the second round candidates and represented with representative colors for them, so that, after their completion, we could identify only two doctrines: social - democratic (represented by red) and liberalism (represented with yellow).

The division of the counties by regions was as follows: a. Banat - Caras - Severin and Timiș counties; b. Crișana - Arad and Bihor counties; c. Dobrogea - Constanța and Tulcea counties; d. Maramureș - Maramureș and Satu Mare counties; e. Moldova - Bacău, Botoșani, Galați, Iași, Neamț, Suceava, Vaslui and Vrancea counties; f. Muntenia - Argeș, Brăila, Buzău, Călărași, Dâmbovița, Giurgiu, Ialomița, Ilfov, Prahova, Teleorman, as well as Bucharest; g. Oltenia - Dolj, Gorj, Mehedinți, Olt and Vâlcea counties; h. Transylvania - Alba, Bistrița- Năsăud, Brașov, Cluj, Covasna, Harghita, Hunedoara, Mureș, Sălaj and Sibiu counties.

\section{RESULTS}

In a general move of confidence, almost the whole of Romania offered the support of the social-democratic party in the 1990 elections, given that it was represented by Ion Iliescu, a prominent public figure at that time, considering his role. in promoting the necessity of the fall of the communist regime. Thus, the social- democratic party recorded high values in all counties, including those in Banat. However, starting with 1992 in the counties of Timiş and Caraș-Severin we observed a diminution of the importance of the social democratic ideology. In 1992 Caraș-Severin county voted with the left-wing party, but since then its majority values have not been registered in the Banat region, with the exception of 2000 (figure 1). In the presidential elections of 2000, we shall observe a new general tendency of voting, at the level of Romania, for the social-democratic ideology, 
but this aspect is accompanied by the racist, xenophobic and extremist characteristics of the liberal candidate of 2000 (Corneliu Vadim Tudor).

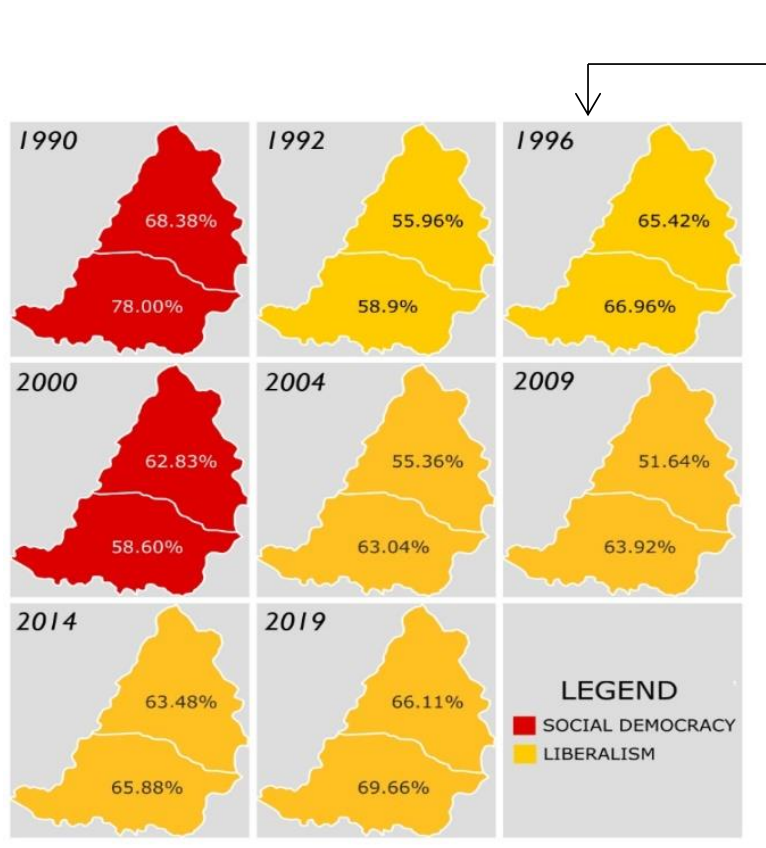

Figure 2. Election results

in Crişana region from 1990 to 2019

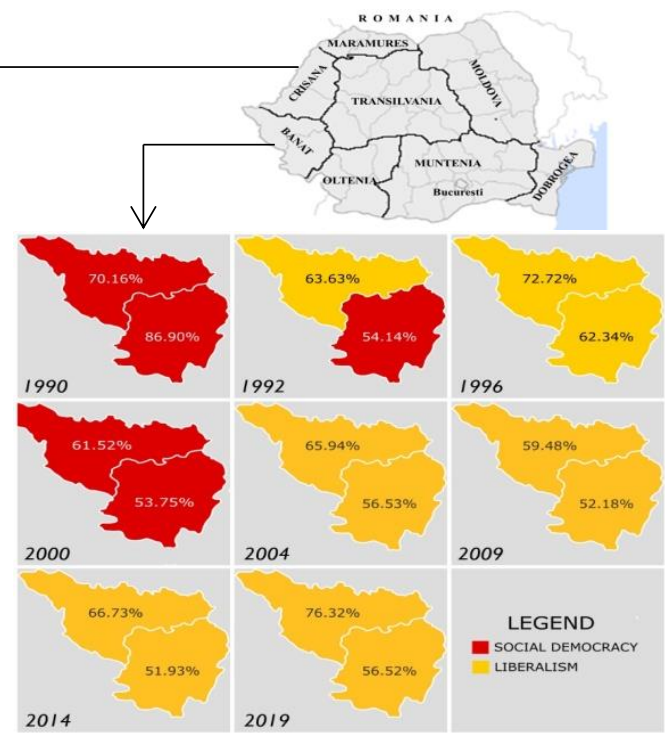

Figure 1. Election results in the Banat region from 1990 to 2019

Also, both counties in Crișana (Arad and Bihor) worked on the common front in all elections, offering their confidence in the social-democratic ideology only because of the image of the candidate Ion Iliescu (1990) and of the public desire of not allowing Corneliu Vadim Tudor to win the elections of in year 2000 (figure 2).

Dobrogen counties have experienced three distinct periods: the period of trust in the social-democratic ideology, either due to the candidate's image, or due to the desire to remove another candidate (1990, 1992 and 2000), the period of differences between the dobrogen counties (1996 - Tulcea a offered their trust to the social - the democrats, while Constantato the liberal ideology), but also the period of total confidence in the liberal doctrine (2004 - 2019) (figure 3). In spite of the hostility with which Ion Iliescu was received in 1992, he gained the trust of the dobrogens through his appearances on the Romanian Television in which he benefited of his previously gained image as a promoter of the Romanian Revolution. Constanta's mass media was extremely vehement regarding the head of state from that period, due to the dispute between a journalist of the newspaper "Telegraph" and the social-democratic candidate.

The citizens of Satu Mare and Maramures counties also experienced four voting tendencies: the period of confidence offered to social- democracy due to the image of the candidate or due to the desire to remove a candidate (1990 and 2000), confidence differently proved in both counties (1992 - Maramures gave their confidence to the left wing party, while Satu Mare offered their full credit to the liberal doctrine), total confidence in the social - democracy (2004 - Adrian Năstase will visit Maramureș and lay the foundations of a new PSD Maramureș headquarters), but also a period of total confidence in liberalism (2009 - 2019). An important aspect is that the confidence of the citizens of Maramureş and Satu mare counties, has steadily increased from 2009 to 2019, upheaving by about 12 percent in Maramures, but also by over 20\% in Satu Mare. The 
Hungarian communities in the border area of Romania in 2019 supported the Liberal candidate through the UDMR representative party, thus the evolution of liberalism in the region was in a positive trend (figure 4).

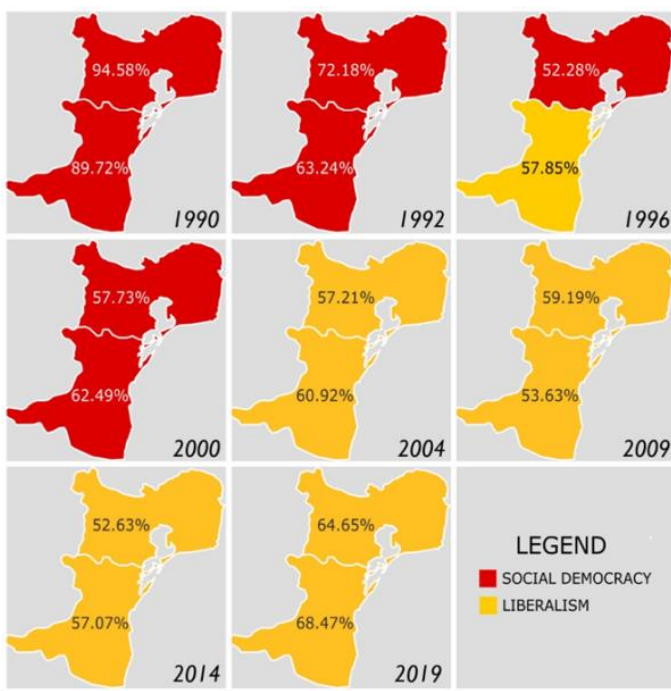

Figure 3. Election results in

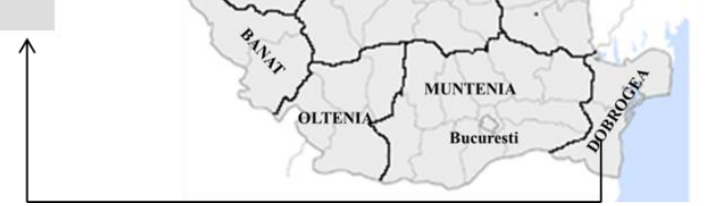

the Dobrogea region from 1990 to 2019

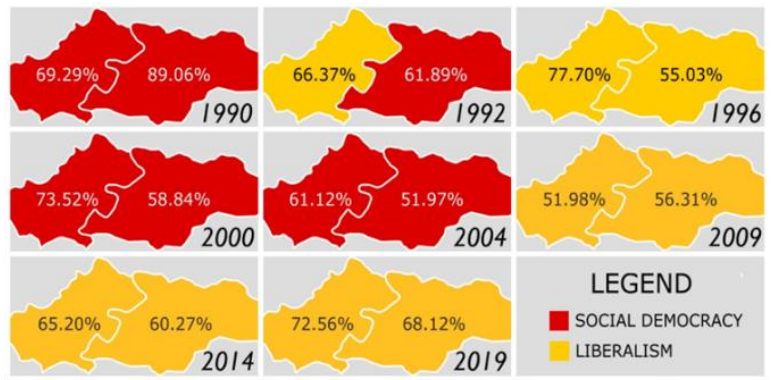

Figure 4. Election results from the Maramures region from 1990 to 2019

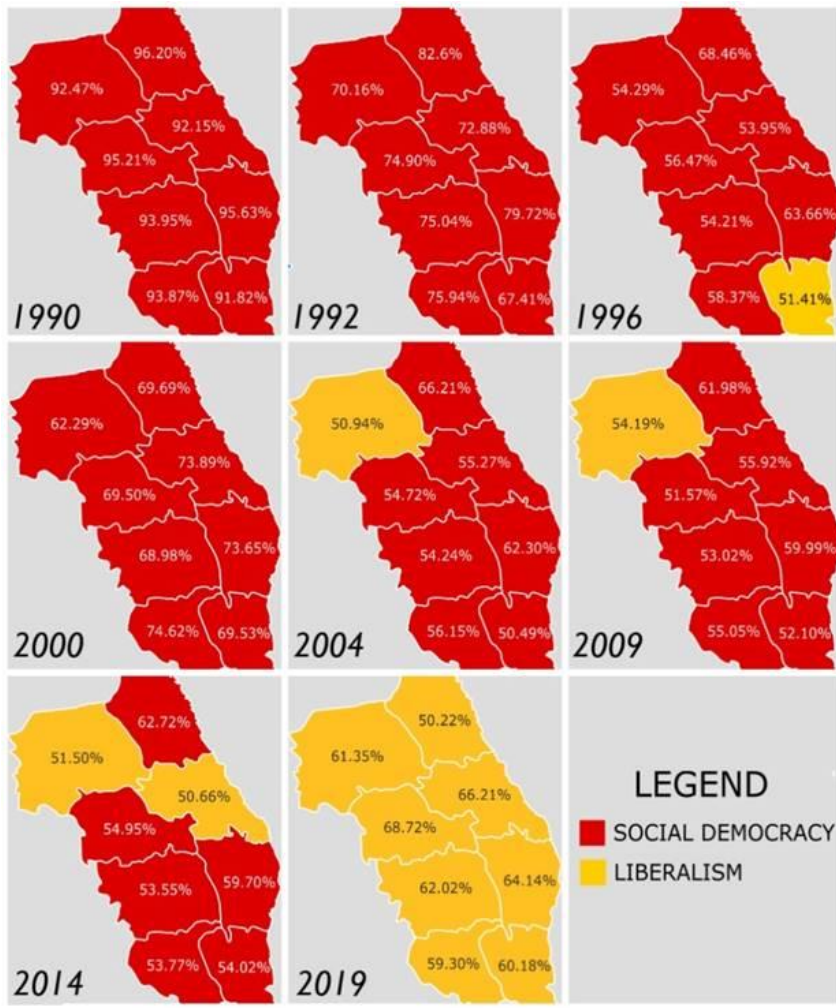

Figure 5. Election results in the region of Moldova from 1990 to 2019 
In the analysis of the region of Moldova we observe a difference of evolution from the regions previously analyzed (figure 5). Thus, for the most part, the Moldovan trust was offered to the social- democrats, with small exceptions. There were 2 exceptions to the extremely interesting rule, namely that Galaţi was the only liberal representative of the elections of 1996, as well as the confidence of Iasi County in liberalism in 2014. Suceava County has been a supporter of the liberal doctrine since 2004, given the numerous visits of the candidate Traian Basescu in the county, who participated in various events, local holidays, visited famous monasteries, but also through his personal visits, given his family connection with Suceava county through direct kinship relationships.

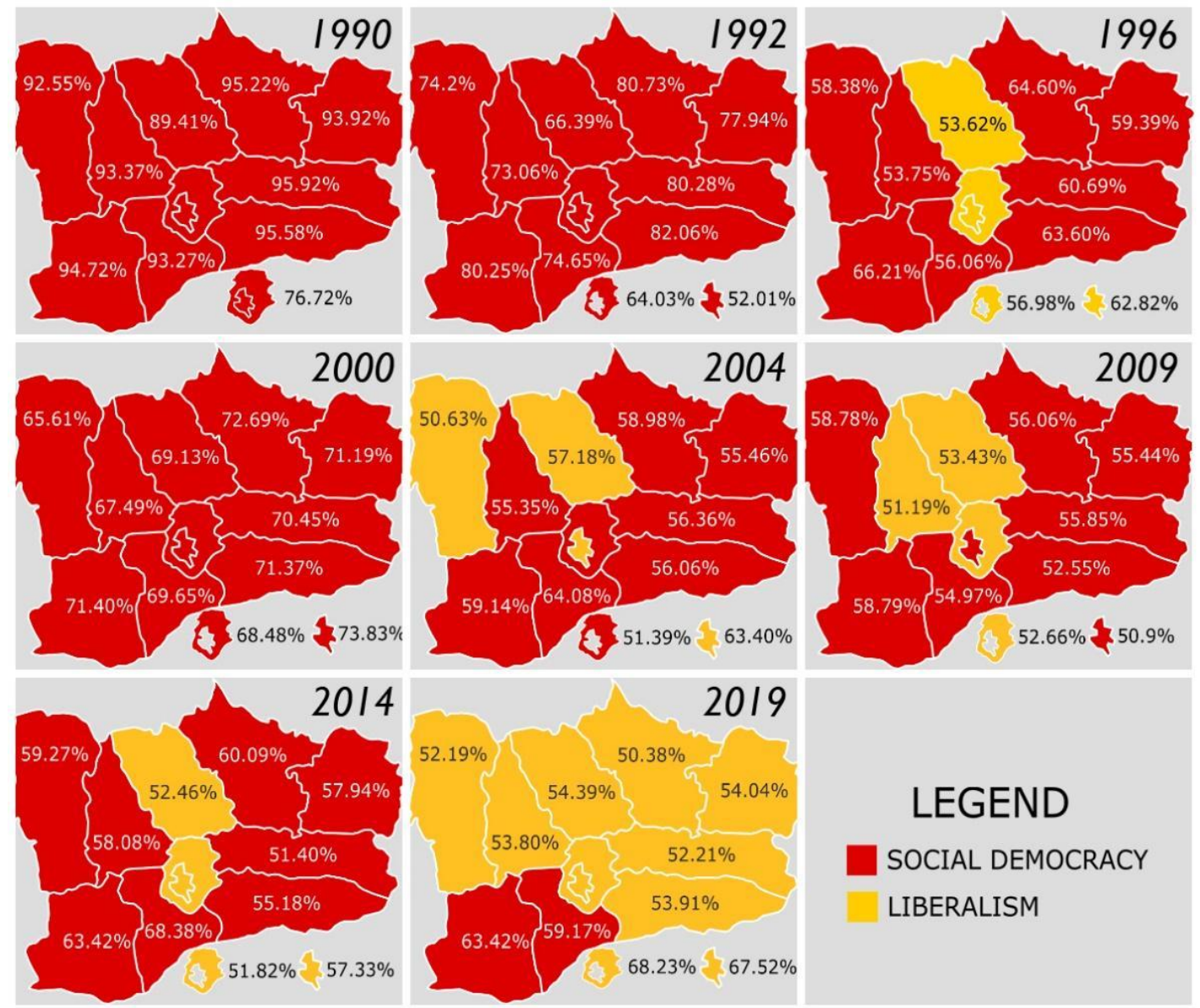

Figure 6. Election results in the Muntenia region from 1990 to 2019

The most important element identified is that the counties in Moldova that are highly dependent on social aid, unemployment benefits or child allowances offer a high confidence to social - democratic parties, except for 2019, when the general trend was approximately similar to the one in 2000 , and a large part of the population voted intentionally against a certain candidate, not just based on trust in a particular ideology. The Muntenia region is officially one of the most economically developed regions, but Prahova County and Bucharest are of the utmost importance. The principle of the balanced relationship between social - democracy and the low economic level is also visible in the counties of Muntenia, especially Giurgiu and Teleorman counties, counties where the social - democratic doctrine has always dominated the vote of the residents (figure 6). However, the situation in Muntenia is at least similar to that of Moldova, with only small inconsistencies in evolution. Bucharest is characterized by a constant 
oscillation between the two ideologies, while Calarasi, Ialomița, Buzău and Brăila represented social- democrat poles between 1990 and 2014.

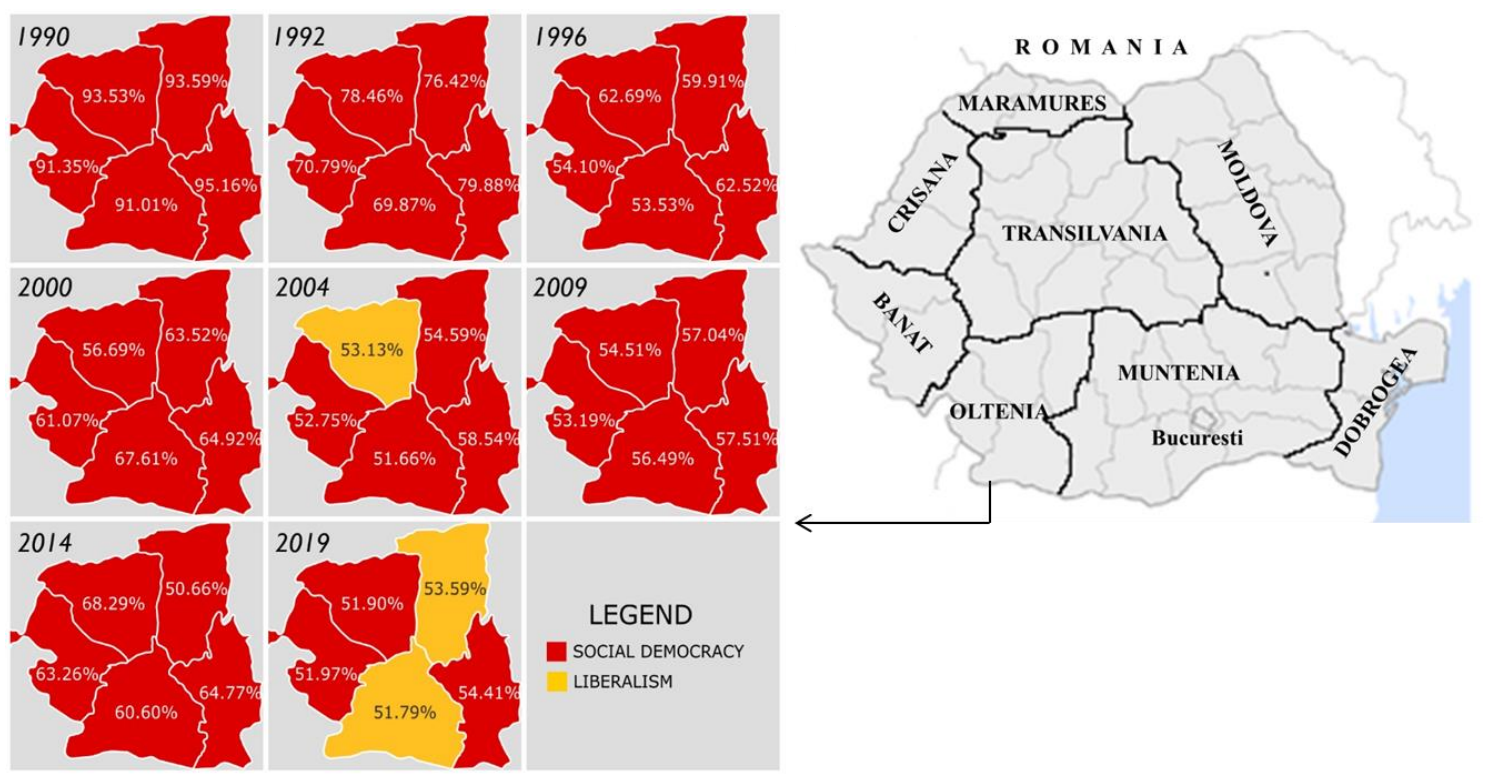

Figure 7. Election results in the Banat region from 1990 to 2019

The high number of unemployed, the valences for agriculture with considerable extra support sources and the dependence on social aid were again a strong point in gaining the confidence of the locals in those counties for the social-democratic parties. Also, the same factors are found in the counties of Oltenia, where we find only three exceptions to the trend: Gorj - 2004, Vâlcea - 2019, Dolj - 2019. Surprising is the fact that although the mayor of Dolj is a representative of the social- democrat party and member of in the social-democratic government, the Doljens preferred Klaus Iohannis in 2019 (figure 7). One of the clearest trends of upward evolution of liberalism we clearly see in Transylvania, where gradually, the share of left- wing parties has decreased considerably. Here we find an extremely interesting situation of the counties with a majority Hungarian population (Covasna, Harghita and Mures), where the representative party of the UDMR has achieved majorities with the parties in power to obtain benefits for the ethnic Hungarians. Thus, in 1990 we see the fact that the Harghita and the Cossacks gave their confidence in an overwhelming proportion to liberalism, while the main pole of affection was Radu Câmpeanu, a promoter of the good relationship between the ethnic Hungarians and the population of Romanians (figure 8). Thus, excepting the year 2000, where the ethnic Hungarians offered an overwhelming share of votes to Ion Iliescu, given the attitude of Corneliu Vadim Tudor towards the importance of the Hungarian population in Romania, we can see a majority increase of liberalism. In 2014 the candidate Klaus Iohannis represented a reliable pole for the Transylvanians due to the fact that he was presented as a former mayor of Sibiu. 


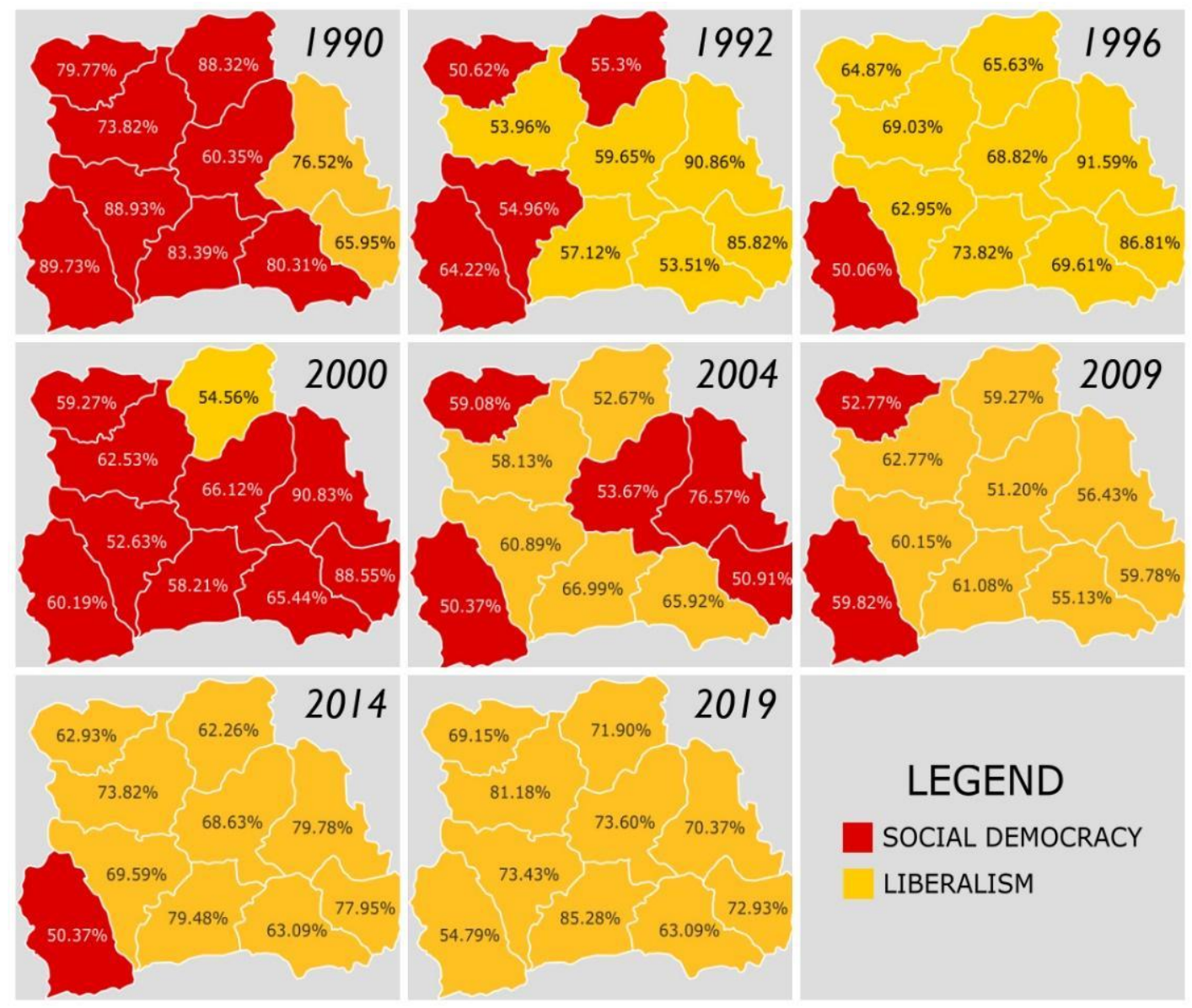

Figure 8. Election results from the Transylvania region from 1990 to 2019

\section{CONCLUSIONS}

In conclusion, we could distinguish a general trend of evolution of liberal doctrine, a tendency sometimes fueled by various factors such as hatred of a certain candidate or of social-democratic doctrine in general. Also, the situation can also be discussed vice versa (2000), but it is extremely interesting to observe the connection between the low level of life- style, the high unemployment rate and the dependence on social aids, children allowances, state financial support, and the tendency of voting of the social- democratic party. Also, the main poles of the Hungarian population have an important role in round 2 by offering votes to the parties that can represent support for them. The regions present, in most cases, a general tendency to trust, with no regions that should include counties that should prefer a certain candidate or doctrine, but only a few exceptions to the rule. Last but not least, the background that a party creates over a certain period of time is important, so that we could refer to two distinct periods: the social- democratic period (1990 - 1996, 2000 - 2004), and the liberal one (1996 - 2000, 2004 - present). The most important element is that from 2004 until now the social-democratic party has not won the presidential elections, which is easily intuitive in that they did not meet the expectations of the people, or they created, involuntarily, a mentality that led to the political disappearance of this doctrine. 


\section{REFERENCES}

[1] Canavilhas Joao, Bittencourt Maira \& Augusto De Andrade, Marco Antonio, Viral Content on Facebook: a case study on the run-up to Brazilian 2018 presidential elections, Brazilian Journalism Research, vol. 15, issue. 3, pp 562-589, 2019.

[2] Dincă Iulian \& Camelia Teodorescu, The Romanian rural space and its landscapes: attraction and motivation for relocating townspeople, Geographia Napocensis, vol. 1, pp 21-36, 201.5

[3] Ekstrom Pierce, Smith Brianna, Williams Allison \& Kim Hannah, Social Network Disagreement and Reasoned Candidate Preferences, American Politics Research, vol. 48, issue. 1, pp 132-154, 2020.

[4] Franz Michael, Fowler Erika Franklin, Ridout Travis \& Wang Meredith Yiran, The Issue Focus of Online and Television Advertising in the 2016 Presidential Campaign, American Politics Research, vol. 48, issue. 1, pp 175-196, 2020.

[5] Grecu Alexandra, Andreea Karina Gruia, Marian Marin, Mariana Bănuță, Cosmin Olteanu, Ionuț Constantin, Mihaela Gadoiu, Camelia Teodorescu, Răzvan Cătălin Dobrea \& Cristian Constantin Drăghici, Specificity of Sustainable Structural Dynamics of Local Economy in Romanian Tourist Resorts, Sustainability, vol. 11, issue.24, pp 7155 - 7167, 2019.

[6] Highton Benjamin, The Cultural Realignment of State white Electorates in the $21^{\text {st }}$ Century, Political Behavior, DOI: 10.1007/s11109-019-09590-5, 2020.

[7] Hill Seth, Hopkins Daniel \& Huber Gregory, Local demodra[phic changes and US presidential voting, 2012 to 2016, Preceedings of the National Academy of Science of the United States of America, vol. 116, issue. 50, pp 25023-25028, 2019.

[8] Hoferer Moritz, Boettcher Lucas, Herrmann, Hans \& Gersbach Hans, The impact of technologies in political campaigns, Physica A - Statistical Mechanics and its Applications, vol. 538, DOI. 10.1016/j.physa.2019.122795, 2020.

[9] Jason Rose \& Aspiras, Olivia, „To hope was to expect”: The impact of perspective taking and forecast type on wishful thinking, Journal of Dehavioral Decision Making, DOI 10.1002/bdm.2170, 2020.

[10] Pintilii Radu-Daniel, Daniel Peptenatu, Ana-Maria Ciobotaru, Sorin George Toma, Ana Maria Grigore, Cristian-Constantin Drăghici, Răzvan-Cătălin Dobrea, Adrian Gabriel Simion, Ion Andronache, Camelia Teodorescu \& Daniel Constantin Diaconu, Creative economies in Romania-spatial projections and trends, Bulletin of Geography. Socio-economic Series, Poland, vol. 37, pp 95-108, 2017.

[11] Stewart Charles, Alvarez R. Michael, Pettigrew Stephen \& Wimpy Cameron, Abstention, Protest and Residual Votes in the 2016 Election, Social Science Quarterly, DOI: 10.1111/ssqu.12757, 2020.

[12] Szemkovics Laurentiu-Stefan, Teodorescu Camelia, Alexandra Grecu, Karina Gruia, Alina Mareci \& Nicoleta Bira, The relevance of the historical monuments in the development of the cultural tourism in the main cities of the region of Oltenia, Romania, Quaestus Journal, Timisoara, Romania, vol. 12, issue. 2, pp. 42-54, 2018

[13] Teodorescu Camelia \& Szemkovics Laurentiu-Stefan, The Ethno-creativity in the Pilot Centers in Romania and their Role in the Development of Cultural Tourism and the Educational Process, Forum geografic Geographical studies and environment protection research, Craiova, Romania, vol. 16, issue.1, pp. 88-97, 2017.

[14] Van Steenburg Eric \& Guzman Francisco, The influence of political candidate brands during the 2012 and 2016 US presidential elections, European Journal of Marketing, vol. 53, issue. 12, pp 2629-2656, 2019. 